\title{
Peningkatan Kemampuan Komunikasi Matematika Siswa SD Kelas V Melalui Tipe Pembelajaran Think Talk Write (TTW)
}

\author{
Novy Trisnani \\ novytrisnani@ipw.ac.id \\ PGSD IKIP PGRI Wates

\begin{abstract}
The Improvement Of Student's Mathematics Communication Ability Of Grade V Elementary School Through Think Talk Write (TTW) Learning Type
\end{abstract}

\begin{abstract}
This study aims to improve the mathematical communication skills of fifth grade students in SD Negeri Kedundang through the application of cooperative learning models of Think Talk Write type. This type of research is classroom action research. The subjects in this study were 19 students. The technique used for data collection is observation and written test techniques. The research instrument is the teacher observation sheets, student observations and written tests. The data analysis technique used is descriptive quantitative and descriptive qualitative. The results of pre-action observation showed that students' communication skills were categorized as very low (47.63\%) and low (38.48\%). Then in the first cycle, students' mathematical communication skills on average increased from very low and low to low (22.60\%), moderate (27.60), and high (22\%). To strengthen the results of observations from the first cycle, the learning activities were held in the second cycle, the results of students' mathematical communication skills increased to the medium category (37.36\%), high (39.47\%), and very high (18.42\%). Based on the results obtained it can be concluded that the application of the think talk write learning model can improve the mathematical communication skills of fifth grade students of Kedundang Elementary School.
\end{abstract}

Keywords: Mathematical Communication Skills, Think Talk Write

\section{Article Info}

Received date: 14 September 2019 Revised date: 10 Januari 2020

Accepted date: 15 Mei 2020

\section{PENDAHULUAN}

Matematika merupakan ilmu universal yang mendasari perkembangan teknologi modern, mempunyai peran penting dalam berbagai disiplin dan memajukan daya pikir manusia (Sofiyah, Surya, \& Syahputra, 2017:1). Untuk menguasai dan mencipta teknologi di masa depan diperlukan penguasaan matematika sejak dini. Melihat pentingnya matematika dan peranannya dalam menghadapi kemajuan ilmu pengetahuan dan teknologi serta persaingan global, maka peningkatan mutu pendidikan terutama pelajaran matematika di semua jenis dan jenjang pendidikan harus selalu diupayakan. Dalam proses pembelajaran di kelas, upaya yang dapat dilakukan guru antara lain dengan melakukan perubahan model pembelajaran, metode pembelajaran, pendekatan pembelajaran, media pembelajaran, dan penilaian pembelajaran.

Kemampuan komunikasi matematika merupakan salah satu kemampuan yang penting untuk dimiliki siswa setelah melaksanakan pembelajaran matematika. Menurut Mahajan (2015: 36), komunikasi yang efektif adalah alat yang paling penting untuk mencapai tujuan keinginan. Kemampuan komunikasi matematika adalah pertukaran ide yang mencakup banyak kemampuan kognitif, diantaranya mendengarkan dan membaca (pemahaman) serta berbicara dan menulis (ekspresi). Khususnya pada matematika, ekspresi juga dapat mencakup representasi ide-ide matematika dengan cara nonlinguistik (Sammons, 2018: 1-2).

Berdasarkan hasil observasi dan wawancara kepada guru kelas V SD Negeri Kedundang, dalam pembelajaran sehari-hari guru sudah pernah menerapkan model pembelajaran yang bervariasi, namun lebih seringnya model pembelajaran yang dipakai guru adalah model pembelajaran konvensional. Model pembelajaran yang sering dipakai dalam pembelajaran matematika di SD Kedundang adalah dengan demonstrasi dan ceramah dan terkadang disertai dengan menggunakan power point. Selama 
observasi, terlihat guru sering sekali kurang memberikan kesempatan kepada siswa untuk memikirkan cara penyelesaian dari suatu permasalahan yang diberikan. Selain itu siswa kurang terbiasa mendiskusikan suatu permasalahan dengan siswa lain, padahal dari berdiskusi siswa akan mendapatkan ide-ide yang dapat menyelesaikan permasalahan yang dihadapi. Hasil kajian lebih lanjut terhadap hasil ulangan harian siswa kelas V di SD Negeri Kedundang tahun ajaran 2018/2019 menunjukkan bahwa kemampuan komunikasi matematika siswa masih rendah. Hasil analisis terhadap hasil belajar siswa dari dokumen ulangan harian siswa menunjukkan bahwa kemampuan siswa menyatakan benda-benda nyata, gambar, atau diagram ke dalam ide-ide matematika masih kurang, mayoritas siswa belum mampu menentukan ide-ide penting dari suatu kalimat dan menyajikannya ke dalam kalimat matematika, serta siswa kurang mampu menentukan pola atau sifat dari gejala matematis untuk membuat generalisasi.

Salah satu model pembelajaran yang dimungkinkan dapat mengakomodir aspek-aspek peningkatan kemampuan komunikasi matematika adalah model pembelajaran kooperatif tipe think talk write (TTW). Think talk write (TTW) merupakan model pembelajaran yang didasarkan pada pemahaman bahwa belajar adalah sebuah perilaku sosial. Model pembelajaran kooperatif tipe think talk write (TTW) mendorong siswa untuk berfikir, berbicara, dan kemudian menuliskan berkenaan dengan suatu topik selain itu strategi think talk write (TTW) memperkenankan siswa untuk mempengaruhi dan memanipulasi ide-ide sebelum menuliskannya (Trisnani, 2012: 45). Model pembelajaran think talk write (TTW) melibatkan 3 tahap penting yang harus dikembangkan dan dilakukan dalam pembelajaran matematika, yaitu think (berpikir/dialog reflektif), talk (berbicara/berdiskusi), dan write (menulis).

Pandangan terhadap penggunaan model pembelajaran TTW untuk meningkatkan kemampuan komunikasi matematika tersebut diperkuat juga dengan hasil penelitian Puspa, Riyadi, dan Subanti (2019: 1) yang menemukan bahwa siswa yang mengungkapkan ide-ide mereka secara lisan dan tulisan, memiliki pemahaman konsep matematika yang lebih tinggi serta dengan mendengarkan pemikiran siswa lain, siswa dapat membangun pikiran mereka dan memperdalam pemahaman mereka tentang konsep pembelajaran.

Berdasarkan uaraian di atas, penulis tertarik melaksanakan penelitian untuk mengetahui ada tidaknya peningkatan kemampuan komunikasi matematika setelah diterapkan model pembelajaran kooperatif tipe think talk write. Penelitian ini diadakan di SD Negeri Kedundang Tahun ajaran 2018/2019, dimana berdasarkan kajian awal, kemampuan komunikasi matematika siswa masih tergolong rendah.

\section{KAJIAN PUSTAKA}

\section{Kemampuan Komunikasi Matematika}

Kemampuan komunikasi matematika sangat penting untuk dikembangkan dalam diri siswa selama proses pembelajaran matematika, yang perlu diingat yaitu bahwa matematika bukan alat untuk sekedar berpikir, tetapi juga alat untuk menyampaikan ide yang jelas dan tepat. Menurut Prayitno, dkk (2013), kemampuan komunikasi matematika adalah kemampuan siswa dalam hal memahami, merepresentasikan, dan menginterpretasikan ide matematika secara lisan dan tulisan. Komunikasi matematika lisan adalah proses menyampaikan ide-ide matematika atau memahami secara lisan dengan berbicara itu, seni transmisi pengetahuan matematika secara langsung ke yang lain (Pantaleon, 2018). Komunikasi lisan (talking) terdiri dari membaca (reading), mendengar (listening), diskusi (discussing), menjelaskan (explainning), dan berbagi (sharing). Komunikasi tulisan (writing) adalah kemampuan atau keterampilan siswa dalam menggunakan kosakata, notasi dan struktur matematika baik dalam bentuk penalaran, koneksi, maupun dalam problem solving, seperti mengungkapkan ide matematika dalam fenomena dunia nyata melalui grafik, tabel, persamaan aljabar, ataupun bahasa sehari-hari (written words).

Menurut Siahaan \& Napitupulu (2018: 232), beberapa indikator kemampuan komunikasi matematika yaitu: 1) kemampuan menyatakan masalah matematika ke dalam model matematika, 2) kemampuan menjelaskan soal-soal matematika menjadi angka, dan 3) kemampuan menjelaskan masalah situasi dengan kata-kata sendiri dan melakukan perhitungan. Diungkapkan dalam NCTM (2000:194) kemampuan komuniksai matematika kelas III-V sekolah dasar harus mencakup kemampuan mengungkapkan pikiran, mengajukan pertanyaan, dan menjelaskan serta membenarkan ide-ide.

Dari uraian diatas maka kemampuan komunikasi matematika adalah kemampuan siswa berupa aktivitas berpikir siswa yang dapat dilihat dari proses membaca suatu teks matematika, membuat catatan 
tentang apa yang dibaca kemudian merefleksikan, menyusun dan menguji ide-ide yang didapatkan, dan menuliskan penyelesaiakan dari suatu masalah matematika dengan pengetahuan yang telah didapatkannya. Adapun jenis kemampuan komunikasi matematika yang akan di teliti adalah kemampuan komunikasi matematika secara tulisan yang meliputi kemampuan menyatakan bendabenda nyata, gambar, dan diagram ke dalam ide matematika, menentukan/menyajikan ide penting ke dalam kalimat matematika, memahami/menafsirkan ide ke dalam bentu gambar/kalimat, melakukan manipulasi matematika, dan menentukan pola atau dugaan dari ekspresi matematis untuk membuat generalisasi.

\section{Think Talk Write}

Huinker dan Laughin (Elliot \& Kenney, 1996: 82) menyatakan bahwa, model pembelajaran think talk write membangun pemikiran, merefleksi, dan mengorganisasi ide, kemudian menguji ide tersebut sebelum siswa diharapkan untuk menulis. Alur kemajuan model pembelajaran think talk write dimulai dari keterlibatan siswa dalam berpikir atau berdialog reflektif dengan dirinya sendiri, selanjutnya berbicara dan berbagi ide dengan temannya, sebelum siswa menulis.

Model pembelajaran kooperatif tipe think talk write melibatkan 3 tahap penting yeng harus dikembangkan dalam pembelajaran matematika, antara lain:

1. Think (berpikir atau dialog reflektif)

Berpikir merupakan berbagai kegiatan yang menggunakan konsep dan lambang sebagai pengganti objek dan peristiwa (Maulidya, 2018). Ditambah oleh Limbach dan Waugh (2010), berpikir adalah proses kognitif untuk memahami lingkungan di sekitarnya, mempertanyakan asumsi sehari-hari yang akan mengarahkan siswa untuk mendapatkan solusi yang diperlukan untuk menyelesaikan masalah. Menurut Yamin \& Ansari (2009: 85) aktivitas berpikir dapat dilihat dari proses membaca suatu teks matematika atau berisi cerita matematika kemudian membuat catatan tentang apa yang telah dibaca.

2. Talk (berbicara atau berdiskusi)

Pada proses talking, hendaknya keadaan berjalan secara alamiah tetapi tidak menulis. Menurut Mishra (2015) talking merupakan cara terbaik untuk menyelesaikan ketidaksepakatan atau kesalahpahaman. Berbicara/ berdiskusi juga melibatkan pertukaran ide, pendapat, dan informasi dengan tujuan tertentu. Selain komunikasi secara lisan, informasi juga dapat dipertukarkan menggunakan simbol atau tanda (Iksan, et.al., 2012: 72).

3. Write (menulis)

Menulis adalah representasi bahasa dalam media tekstual melalui penggunaan serangkaian tanda atau symbol yang disebut sistem penulisan (Schneider, 2011). Menurut Fathoni, Sumardi, \& Supriyadi (2019: 69), melalui menulis, siswa dapat membagikan perasaan, gagasan, pemikiran, informasi, dan pengalaman mereka dengan kata-kata tertulis. Hal ini dapat membantu siswa memperdalam dan memperluas pemahaman mereka. Pada tahap menulis, siswa diminta untuk menuliskan penyelesaian dan kesimpulan dari masalah yeng telah diberikan. Apa yang dituliskan siswa pada tahap ini mungkin berbeda dengan apa yang mereka tuliskan pada catatan individual (tahap think). Hal ini terjadi karena setelah siswa berdiskusi ia akan memperoleh ide baru untuk menyelesaikan masalah yang diberikan.

Berdasarkan uraian di atas, maka langkah-langkah pembelajaran menggunakan model pembelajaran think talk write yaitu: langkah think, pada tahap ini Pada tahap ini siswa secara individu memikirkan kemungkinan jawaban/strategi penyelesaian, membat catatan kecil tentang ide-ide yang terdapat dalam bacaan, dan hal-hal yang tidak dipahaminya dengan bahasanya sendiri. langkah kedua adalah talk, pada tahap ini siswa diberi kesempatan untuk merefleksikan, menysusn, dan menguji ideide ke dalam kegiatan dalam diskusi kelompok. Langkah ketiga write, pada tahap ini siswa akan belajar melakukan komunikasi secara tulisan, dari hasil diskusi siswa diminta untuk menuliskan penyelesaian dan kesimpulan dari masalah yang telah diberikan.

\section{METODE PENELITIAN}

Penelitian ini merupakan Penelitian Tindakan Kelas (Classroom Action Research). Tindakan yang diberikan adalah proses pembelajaran dengan menerapkan model pembelajaran think talk write (TTW). Penelitian ini dilaksanakan di SD Negeri Kedundang dengan subyek penelitian adalah siswa 
kelas V sebanyak 19 siswa. Penelitian ini dilaksanakan pada semester I tahun ajaran 2018/2019. Adapun cara pengumpulan data yang dilakukan dalam penelitian ini adalah dengan tes untuk mengetahui data mengenai kemampuan komunikasi matematika siswa yang diberikan kepada siswa pada setiap akhir pertemuan siklus, lembar observasi untuk mengetahui data mengenai keaktifan siswa dan kegiatan proses belajar mengajar diambil dengan menggunakan lembar observasi, dan angket untuk mengetahui data mengenai respons siswa terhadap pembelajaran dengan model TTW. Data hasil pengamatan dianalisa secara kuantitatif dan kualitatif. Untuk analisis secara kuantitatif digunakan statistik deskriptif untuk mendeskripsikan kemampuan komunikasi matematika setelah dilakukan pembelajaran dengan menerapkan model TTW. Data hasil observasi dianalisis secara kualitatif.

\section{HASIL DAN PEMBAHASAN}

\section{Kondisi Awal}

Kondisi awal kemampuan komunikasi matematika merupakan hasil tes yang dilakukan pada siswa kelas V SD Negeri Kedundang yang dinilai oleh peneliti sebelum diadakan penelitian. Untuk mengukur kemampuan komunikasi matematika digunakan soal tes matematika pada materi bangun datar dan bangun ruang sebanyak 4 soal.

Tabel 1. Distribusi Kemampuan Komunikasi Matematika Siswa Kelas V SD Negeri Kedundang pada Kondisi Awal

\begin{tabular}{|c|c|c|c|c|c|c|c|}
\hline & $\begin{array}{c}\text { Indikator Kemampuan Komunikasi } \\
\text { Matematika }\end{array}$ & $\begin{array}{l}\text { Soal } \\
\text { No. }\end{array}$ & $\begin{array}{l}\text { Sangat } \\
\text { Rendah }\end{array}$ & Rendah & Sedang & Tinggi & $\begin{array}{l}\text { Sangat } \\
\text { Tinggi }\end{array}$ \\
\hline \multirow[t]{4}{*}{1.} & Menyatakan benda-benda nyata, gambar, & 1 & 8 & 5 & 5 & 1 & \\
\hline & dan diagram ke dalam ide matematika & 2 & 7 & 8 & 3 & 1 & \\
\hline & & 3 & 9 & 7 & 3 & 0 & \\
\hline & & 4 & 6 & 10 & 3 & 0 & \\
\hline & Menentukan/menyajikan ide penting ke & 1 & 12 & 5 & 2 & 0 & \\
\hline & dalam kalimat matematika & 2 & 9 & 8 & 2 & 0 & \\
\hline & & 3 & 8 & 4 & 5 & 2 & \\
\hline & & 4 & 10 & 6 & 2 & 1 & \\
\hline & Memahami/menafsirkan ide ke dalam & 1 & 12 & 5 & 2 & 0 & \\
\hline & bentuk gambar/kalimat & 2 & 12 & 6 & 1 & 0 & \\
\hline & & 3 & 10 & 7 & 2 & 0 & \\
\hline & & 4 & 9 & 10 & 0 & 0 & \\
\hline & Melakukan manipulasi matematika & 1 & 7 & 8 & 3 & 1 & \\
\hline & & 2 & 9 & 9 & 1 & 0 & \\
\hline & & 3 & 8 & 8 & 1 & 2 & \\
\hline & & 4 & 8 & 7 & 3 & 1 & \\
\hline \multirow[t]{4}{*}{5.} & Menentukan pola atau dugaan dari ekspresi & 1 & 10 & 7 & 2 & 0 & \\
\hline & matematis untuk membuat generalisasi & 2 & 9 & 8 & 2 & 0 & \\
\hline & & 3 & 10 & 9 & 0 & 0 & \\
\hline & & 4 & 8 & 10 & 1 & 0 & \\
\hline
\end{tabular}

Berdasarkan dari tabel, indikator menyatakan benda-benda nyata, gambar, dan diagram ke dalam ide matematika siswa tergolong sangat rendah sebanyak 39,47\%, kategori rendah sebanyak $39,47 \%$, kategori sedang $18,42 \%$, dan kategori tinggi sebanyak 2,63\%. Pada indikator menentukan/menyajikan ide penting ke dalam kalimat matematika siswa tergolong sangat rendah sebanyak $51,31 \%$, kategori rendah sebanyak $30,26 \%$, kategori sedang $14,47 \%$, dan kategori tinggi sebanyak $3,94 \%$. Pada indikator memahami/menafsirkan ide ke dalam bentuk gambar/kalimat siswa tergolong sangat rendah sebanyak 56,58\%, kategori rendah sebanyak 36,84\%, dan kategori sedang sebanyak $6,58 \%$. Pada indikator melakukan manipulasi matematika siswa sangat rendah sebanyak $42,1 \%$, kategori rendah sebanyak 42,1\%, kategori sedang $10,5 \%$, dan kategori tinggi sebanyak 5,26\%. Pada indikator menentukan pola atau dugaan dari ekspresi matematis untuk membuat generalisasi siswa dengan kemampuan komunikasi sangat rendah sebanyak 46,68\%, kategori rendah sebanyak 44,73\%, dan kategori sedang $6,58 \%$. Tabel hasil kemampuan komunikasi matematika kemudian dirangkum 
Peningkatan Kemampuan Komunikasi Matematika Siswa SD Kelas V Melalui Tipe Pembelajaran Think Talk Write (TTW) (Novy Trisnani)

dalam tabel distribusi dan persentase skor kemampuan komunikasi matematika siswa kelas V SD Negeri Kedundang sebagai berikut.

Tabel 2. Distribusi Frekuensi dan Persentase Skor Kemampuan Komunikasi Matematika Siswa Kelas V SD Negeri Kedundang pada Siklus I

\begin{tabular}{ccccc}
\hline Skor & Tingkat Kemampuan & Kategori & Frekuensi & Persentase \\
\hline $0-34$ & $0 \%-34 \%$ & Sangat Rendah & 181 & 47,63 \\
\hline $35-54$ & $35 \%-54 \%$ & Rendah & 147 & 38,68 \\
\hline $55-64$ & $55 \%-64 \%$ & Sedang & 43 & 11,32 \\
\hline $65-84$ & $65 \%-84 \%$ & Tinggi & 9 & 2,37 \\
\hline $84-100$ & $84 \%-100 \%$ & Sangat Tinggi & 0 & 0 \\
\hline
\end{tabular}

Berdasarkan data dari tabel, dari 19 anak diketahui sebesar 47,63 \% anak mempunyai kemampuan komunikasi matematika sangat rendah, 38,68 mempunyai kemampuan komunikasi rendah, 11,32 memiliki kemampuan komunikasi sedang, dan 2, 37 mempunyai kemampuan komunikasi tinggi.

\section{Deskripsi Data Siklus 1}

Perencanaan Tindakan

Pada tahap perencanaan tindakan pada siklus I, peneliti melakukan kegiatan pengembangan pembelajaran yang dilaksanakan selama 2 kali pertemuan yaitu dengan menerapkan model pembelajaran think talk write. Berikut ini akan disajikan data pada siklus I terhadap penerapan model pembelajaran think talk write materi bangun datar dan bangun ruang. Untuk mengukur kemampuan komunikasi matematika pada siklus I pertemuan 1, siswa berikan soal tes berupa soal uraian sebanyak 4 butir soal. Adapun hasilnya adalah sebagai berikut:

Tabel 3. Hasil Observasi Kemampuan Komunikasi Mtematika Siswa Kelas V SD Negeri Kedundang pada Siklus I Pertemuan 1

\begin{tabular}{|c|c|c|c|c|c|c|c|c|c|c|}
\hline \multirow{2}{*}{$\begin{array}{c}\text { Indikator Kemampuan } \\
\text { Komunikasi Matematika }\end{array}$} & \multicolumn{5}{|c|}{ Frekuensi } & \multicolumn{5}{|c|}{ Persentase } \\
\hline & SR & $\mathbf{R}$ & $\mathbf{S}$ & $\mathbf{T}$ & ST & SR & $\mathbf{R}$ & $\mathbf{S}$ & $\mathbf{T}$ & ST \\
\hline $\begin{array}{l}\text { 1. Menyatakan benda-benda nyata, } \\
\text { gambar, dan diagram ke dalam } \\
\text { ide matematika }\end{array}$ & 20 & 29 & 19 & 8 & 0 & 21,74 & 31,52 & 20,65 & 8,69 & 0 \\
\hline $\begin{array}{l}\text { 2. Menentukan/menyajikan ide } \\
\text { penting ke dalam kalimat } \\
\text { matematika }\end{array}$ & 17 & 35 & 13 & 8 & 3 & 18,47 & 38,04 & 14,13 & 8,69 & 3,26 \\
\hline $\begin{array}{l}\text { 3. Memahami/menafsirkan ide ke } \\
\text { dalam bentuk gambar/kalimat }\end{array}$ & 16 & 36 & 16 & 5 & 3 & 17,39 & 39,13 & 17,39 & 5,43 & 3,26 \\
\hline $\begin{array}{lll}\text { 4. } & \begin{array}{l}\text { Melakukan } \\
\text { matematika }\end{array} & \text { manipulasi } \\
\end{array}$ & 15 & 21 & 21 & 17 & 2 & 16,30 & 22,82 & 22,82 & 18,47 & 2,21 \\
\hline $\begin{array}{l}\text { 5. Menentukan pola atau dugaan } \\
\text { dari ekspresi matematis untuk } \\
\text { membuat generalisasi }\end{array}$ & 20 & 30 & 10 & 16 & 0 & 21,73 & 32,6 & 10,87 & 17,39 & 0 \\
\hline Jumlah & 88 & 151 & 79 & 54 & 8 & 95,63 & 164,1 & 85,86 & 58,7 & 8,73 \\
\hline Rata-rata & 17,6 & 30,2 & 15,8 & 10,8 & 1,6 & 19,12 & 32,82 & 17,17 & 11,73 & 1,76 \\
\hline
\end{tabular}

Berdasarkan dari tabel, indikator menyatakan benda-benda nyata, gambar, dan diagram ke dalam ide matematika siswa tergolong sangat rendah sebanyak $21,74 \%$, kategori rendah sebanyak $31,52 \%$, kategori sedang 20,65\%, dan kategori tinggi sebanyak 8,69\%. Pada indikator menentukan/menyajikan ide penting ke dalam kalimat matematika siswa tergolong sangat rendah sebanyak $18,47 \%$, kategori rendah sebanyak $38,04 \%$, kategori sedang $14,13 \%$, kategori tinggi sebanyak $8,69 \%$, dan kategori sangat tinggi sebanyak $17,39 \%$. Pada indikator memahami/menafsirkan ide ke dalam bentuk gambar/kalimat siswa tergolong sangat rendah sebanyak 17,39\%, kategori rendah sebanyak39,13\%, dan kategori sedang sebanyak 10,87\%. Pada indikator melakukan manipulasi matematika siswa sangat rendah sebanyak $16,30 \%$, kategori rendah sebanyak $22,82 \%$, kategori sedang $22,87 \%$, kategori tinggi sebanyak $18,47 \%$, dan kategori sangat tinggi sebanya $2,21 \%$. Pada indikator menentukan pola atau dugaan dari ekspresi matematis untuk membuat generalisasi siswa dengan 
kemampuan komunikasi sangat rendah sebanyak $21,73 \%$, kategori rendah sebanyak $32,6 \%$, kategori sedang $10,87 \%$, dan pada kategori tinggi sebanyak $17,39 \%$.

Tabel 4. Hasil Observasi Kemampuan Komunikasi Matematika Siswa Kelas V SD Negeri Kedundang pada Siklus I Pertemuan 2

\begin{tabular}{|c|c|c|c|c|c|c|c|c|c|c|}
\hline \multirow{2}{*}{$\begin{array}{l}\text { Indikator Kemampuan Komunikasi } \\
\text { Matematika }\end{array}$} & \multicolumn{5}{|c|}{ Frekuensi } & \multicolumn{5}{|c|}{ Persentase } \\
\hline & SR & $\mathbf{R}$ & $\mathbf{S}$ & $\mathbf{T}$ & ST & SR & $\mathbf{R}$ & $\mathbf{S}$ & $\mathbf{T}$ & ST \\
\hline $\begin{array}{l}\text { 1. Menyatakan benda-benda nyata, } \\
\text { gambar, dan diagram ke dalam ide } \\
\text { matematika }\end{array}$ & 0 & 21 & 29 & 19 & 7 & 0 & 22,82 & 31,52 & 20,65 & 7,61 \\
\hline $\begin{array}{l}\text { 2. } \begin{array}{l}\text { Menentukan/menyajikan } \\
\text { penting ke dalam kalimat } \\
\text { matematika }\end{array} \\
\end{array}$ & 3 & 24 & 27 & 14 & 8 & 3,26 & 26,09 & 29,34 & 15,21 & 8,69 \\
\hline $\begin{array}{l}\text { 3. Memahami/menafsirkan ide ke } \\
\text { dalam bentuk gambar/kalimat }\end{array}$ & 1 & 23 & 22 & 23 & 7 & 1,09 & 25 & 23,91 & 25 & 7,60 \\
\hline 4. Melakukan manipulasi matematika & 2 & 14 & 25 & 29 & 6 & 2,17 & 15,21 & 27,17 & 31,52 & 6,52 \\
\hline $\begin{array}{l}\text { 5. Menentukan pola atau dugaan dari } \\
\text { ekspresi matematis untuk membuat } \\
\text { generalisasi }\end{array}$ & 3 & 22 & 24 & 16 & 4 & 3,26 & 23,91 & 26,01 & 17,39 & 4,35 \\
\hline Jumlah & 9 & 104 & 127 & 101 & 32 & 9,78 & 113 & 138 & 109,8 & 34,7 \\
\hline Rata-rata & 1,8 & 20,8 & 25,4 & 20,2 & 6,4 & 1,96 & 22,6 & 27,6 & 22 & 6,9 \\
\hline
\end{tabular}

Berdasarkan dari tabel, indikator menyatakan benda-benda nyata, gambar, dan diagram ke dalam ide matematika siswa tergolong kategori rendah sebanyak $22,82 \%$, kategori sedang $31,52 \%$, dan kategori tinggi sebanyak 20,65\%, dan kategori sangat tinggi sebanyak 7,61\%. Pada indikator memahami/menafsirkan ide ke dalam bentuk gambar/kalimat siswa tergolong sangat rendah sebanyak $3,26 \%$, kategori rendah sebanyak 26,09\%, dan kategori sedang sebanyak 29,34\%, kategori tinggi sebanyak $15,21 \%$, dan kategori sangat tinggi sebanyak $8,69 \%$. Pada indikator melakukan manipulasi matematika siswa sangat rendah sebanyak $1,09 \%$, kategori rendah sebanyak $25 \%$, kategori sedang $23,91 \%$, kategori tinggi sebanyak 25\%, dan kategori sangat tinggi sebanya 7,60\%. Pada indikator menentukan pola atau dugaan dari ekspresi matematis untuk membuat generalisasi siswa dengan kemampuan komunikasi sangat rendah sebanyak 3,26\%, kategori rendah sebanyak $23,91 \%$, kategori sedang $26,01 \%$, kategori tinggi sebanyak $17,39 \%$, dan kategori sangat tinggi sebanyak 4,35\%.

\section{Observasi Siklus 1}

Berdasarkan tabel hasil penilaian observasi pada siklus 1 pertemuan 1 dan 2 di atas maka dapat diketahui bahwa kemampuan komunikasi matematika siswa kelas V SD Negeri Kedundang mengalami peningkatan. Hal tersebut terlihat dari data yang disajikan dalam tabel berikut ini:

Tabel 5. Rangkuman Persentase Peningkatan Kemampuan Komunikasi Matematika Siswa Kelas V SD Negeri Kedundang di Siklus I pertemuan 1 dan 2

\begin{tabular}{ccc}
\hline \multirow{2}{*}{ Kategori Kemampuan Komunikasi Matematika } & \multicolumn{2}{c}{ Siklus 1 } \\
\cline { 2 - 3 } & Pertemuan 1 & Pertemuan 2 \\
\hline Sangat Rendah (SR) & $19,12 \%$ & $1,96 \%$ \\
Rendah (R) & $32,82 \%$ & $22,6 \%$ \\
Sedang (S) & $17,17 \%$ & $27,6 \%$ \\
Tinggi (T) & $11,73 \%$ & $22 \%$ \\
Sangat Tinggi (ST) & $1,76 \%$ & $6,9 \%$ \\
\hline
\end{tabular}

Kemampuan komunikasi matematika siswa dari kategori rendah pada siklus I pertemuan 1 sebesar $19,12 \%$ menurun menjadi $1,96 \%$, kategori rendah paa pertemuan 1 sebesar $32,82 \%$ pada pertemuan 2 menurun menjadi 22,6\%, kategori senag meningkat dari 17,17\% menjadi 27,6\% pada pertemuan 2, kategori tinggi sebesar $11,73 \%$ meningkat menjadi $22 \%$, dan kategori sangat tinggi sebesar $1,76 \%$ meningkat menjadi $6,9 \%$ pada pertemuan 2. Grafik Peningkatan Kemampuan Komunikasi matematika siswa kelas V SD Negeri Kedundang pada Siklus I pertemuan 1 dan pertemuan 2 
Peningkatan Kemampuan Komunikasi Matematika Siswa SD Kelas V Melalui Tipe Pembelajaran Think Talk Write (TTW) (Novy Trisnani)

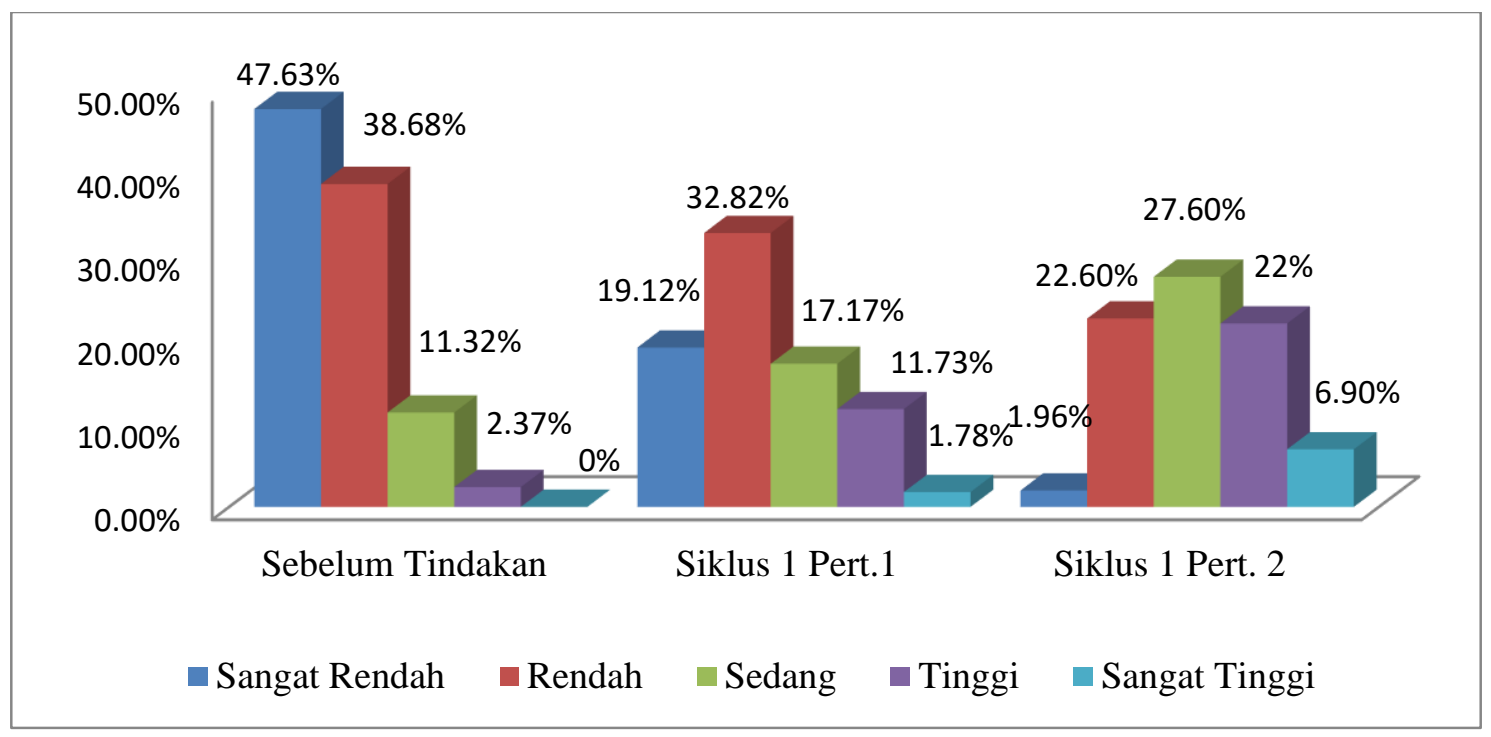

Gambar 1. Grafik Komparasi Hasil Tindakan Siklus 1

\section{Refleksi Siklus I}

Berdasarkan perolehan hasil tes tindakan yang diberikan pada siklus I, telah terjadi peningkatan kemampuan komunikasi matematika siswa kelas V SD Negeri Kedundang sesuai indikator yang telah ditentukan. Pada observasi aktivitas guru dan siswa secara keseluruhan sudah dalam kategori baik, namun masih ada sedikit yang perlu diperbaiki. Untuk memperkuat hasil observasi yang juga merupakan hasil penelitian pada siklus I pertemuan 1 dan pertemuan 2, maka tidakan yang dilakukan adalah mengadakan kegiatan pembelajaran pada siklus II.

\section{Siklus II}

\section{Perencanaan Siklus II}

Pada tahap perencanaan tindakan pada siklus II, peneliti melakukan kegiatan antara lain merencanakan pelaksanaan pembelajaran. Selain itu peneliti juga mempersiapkan rencana dan langkah kegiatan pembelajaran yang telah diperbaharui sebagai tindakan perbaikan. Tindakan perbaikan ini dimaksudkan untuk dapat memperoleh peningkatan persentase kemampuan komunikasi matematika serta mempertahankan hasil observasi/hasil penelitian pada siklus I. Pada siklus II dilaksanakan tindakan selama 1 kali pertemuan. Berikut ini akan disajikan data Siklus II yang telah dilaksanakan dengan lebih fokus, yaitu sebagai berikut:

Tabel 6. Hasil Observasi Kemampuan Komunikasi Matematika Siswa Kelas V SD Negeri Kedundang pada Siklus II Pertemuan 1

\begin{tabular}{|c|c|c|c|c|c|c|c|c|c|c|}
\hline \multirow{2}{*}{$\begin{array}{c}\text { Indikator Kemampuan Komunikasi } \\
\text { Matematika }\end{array}$} & \multicolumn{5}{|c|}{ Frekuensi } & \multicolumn{5}{|c|}{ Persentase } \\
\hline & SR & $\mathrm{R}$ & $S$ & $\mathrm{~T}$ & ST & SR & $\mathrm{R}$ & $\mathrm{S}$ & $\mathrm{T}$ & ST \\
\hline $\begin{array}{l}\text { 1. Menyatakan benda-benda nyata, } \\
\text { gambar, dan diagram ke dalam ide } \\
\text { matematika }\end{array}$ & 0 & 6 & 30 & 26 & 14 & 0 & 7,89 & 39,47 & 34,21 & 18,42 \\
\hline $\begin{array}{l}\text { 2. Menentukan/menyajikan ide penting } \\
\text { ke dalam kalimat matematika }\end{array}$ & 0 & 4 & 29 & 29 & 14 & 0 & 5,26 & 38,15 & 38,15 & 18,42 \\
\hline $\begin{array}{l}\text { 3. Memahami/menafsirkan ide ke } \\
\text { dalam bentuk gambar/kalimat }\end{array}$ & 0 & 4 & 28 & 32 & 12 & 0 & 5,26 & 36,84 & 42,10 & 15,79 \\
\hline 4. Melakukan manipulasi matematika & 0 & 2 & 26 & 35 & 15 & 0 & 2,63 & 34,21 & 46,05 & 19,73 \\
\hline $\begin{array}{l}\text { 5. Menentukan pola atau dugaan dari } \\
\text { ekspresi matematis untuk membuat } \\
\text { generalisasi }\end{array}$ & 0 & 4 & 29 & 28 & 15 & 0 & 5,26 & 38,15 & 36,84 & 19,73 \\
\hline Jumlah & 0 & 20 & 142 & 150 & 70 & 0 & 26,31 & 186,84 & 197,36 & 92,1 \\
\hline Rata-rata & 0 & 4 & 28,4 & 30 & 14 & 0 & 5,26 & 37,36 & 39,47 & 18,42 \\
\hline
\end{tabular}


Berdasarkan dari tabel, indikator menyatakan benda-benda nyata, gambar, dan diagram ke dalam ide matematika siswa tergolong kategori rendah sebanyak 7,89\%, kategori sedang $39,472 \%$, dan kategori tinggi sebanyak 34,21\%, dan kategori sangat tinggi sebanyak 18,42\%. Pada indikator memahami/menafsirkan ide ke dalam bentuk gambar/kalimat siswa tergolong kategori rendah sebanyak $5,26 \%$, dan kategori sedang sebanyak 36,84\%, kategori tinggi sebanyak 42,10\%, dan kategori sangat tinggi sebanyak $15,79 \%$. Pada indikator melakukan manipulasi matematika siswa rendah sebanyak $2,63 \%$, kategori sedang sebanyak 34,21\%, kategori tinggi 46,05\%, dan kategori sangat tinggi sebanya $19,73 \%$. Pada indikator menentukan pola atau dugaan dari ekspresi matematis untuk membuat generalisasi siswa dengan kemampuan komunikasi siswa kategori rendah sebanyak 5,26\%, kategori sedang $38,15 \%$, kategori tinggi sebanyak $36,84 \%$, dan kategori sangat tinggi sebanyak $19,73 \%$.

\section{Obeservasi Siklus II}

Tabel 7. Rangkuman Persentase Peningkatan Kemampuan Komunikasi Matematika Siswa Kelas V SD Negeri Kedundang pada Siklus II

\begin{tabular}{|c|c|}
\hline \multirow{2}{*}{$\begin{array}{c}\text { Kategori Kemampuan } \\
\text { Komunikasi Matematika }\end{array}$} & Siklus II \\
\hline & Pertemuan 1 \\
\hline Sangat Rendah (SR) & $0 \%$ \\
\hline Rendah $(\mathrm{R})$ & $5,26 \%$ \\
\hline Sedang (S) & $37,36 \%$ \\
\hline Tinggi $(\mathrm{T})$ & $39,47 \%$ \\
\hline Sangat Tinggi (ST) & $18,42 \%$ \\
\hline Sangat Tinggi (ST) & $1,76 \%$ \\
\hline
\end{tabular}

Berdasarkan data pada tabel di atas, kemampuan komunikasi matematika siswa dari kategori rendah pada siklus I pertemuan2 sebesar $1,96 \%$ menurun menjadi $0 \%$ pada siklus II pertemuan 1 , kategori rendah pada pertemuan 22,6\% menurun menjadi 5,26\%, kategori sedang meningkat dari 27,6\% pada siklus I pertemuan 2 menjadi 37,36\%, kategori tinggi sebesar 22\% meningkat menjadi 39,47\%, dan kategori sangat tinggi sebesar 6,9\% meningkat menjadi 18,42\% pada siklus II pertemuan 1 . Grafik Peningkatan Kemampuan Komunikasi matematika siswa kelas V SD Negeri Kedundang pada Siklus I pertemuan 1 dan pertemuan 2, dan Siklus II.

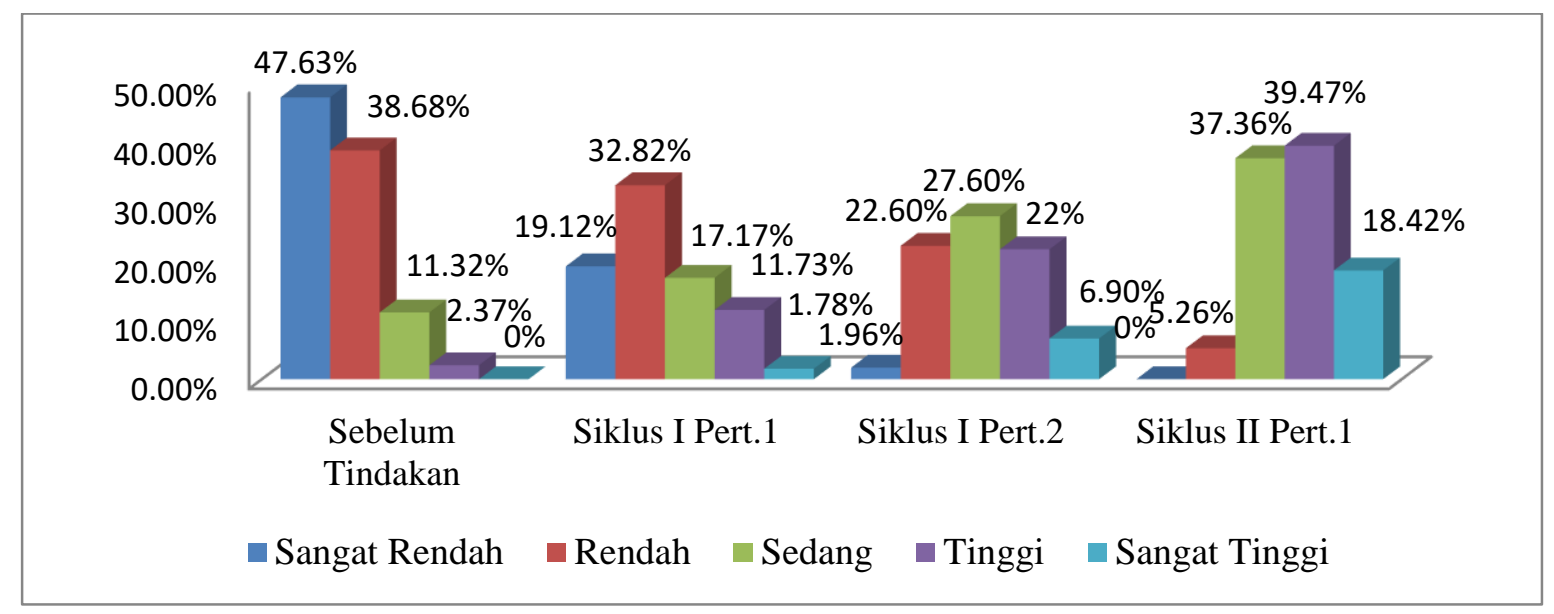

Gambar 2. Grafik Komparasi Hasil Tindakan Siklus 2

\section{Refleksi Siklus II}

Dari Observasi Siklus II didapat bahwa kemampuan komunikasi matematika siswa kelas V SD Negeri Kedundang mengalami penurunan jumlah siswa yang masuk pada kategori sangat rendah, dan rendah, meningkat menjadi kemampuan komunikasi matematika kategori sedang, tinggi, dan sangat tinggi.peningkatan setelah menggunakan metode pembelajaran think talk write. Hasil observasi pada siklus II sekaligus memperkuat hasil observasi/penelitian pada siklus I. Karena Kemampuan komunikasi matematika siswa kelas V SD Negeri Kedundang telah mengalami peningkatan sesuai dengan indikator yang telah ditentukan, maka kegiatan siklus dihentikan pada siklus II pertemuan 1. 


\section{Pembahasan}

Penerapan model pembelajaran kooperatif tipe think talk write pada siswa kelas V SD Negeri Kedundang dilaksanakan melalui tiga tahapan pembelajaran. Secara umum langkah-langkah pada model pembelajaran think talk write mampu meningkatkan keseluruhan indikator kemampuan komunikasi matematika. Indikator kemampuan komunikasi matematika yang dipakai dalam penelitian ini adalah menyatakan benda-benda nyata, gambar, dan diagram ke dalam ide matematika siswa tergolong, memahami/menafsirkan ide ke dalam bentuk gambar/kalimat, melakukan manipulasi matematika, menentukan pola atau dugaan dari ekspresi matematis untuk membuat generalisasi siswa dengan kemampuan komunikasi.

Pada tahap think siswa diberikan bacaan atau suatu permasalahan matematika kemudian diminta untuk membuat catatan individu (tentang hal-hal yang diketahui dan tidak diketahui) dan dibawa ke forum diskusi. Pada tahap ini siswa dipaksa dan didorong untuk mengeksplorasi diri mereka sendiri untuk menyajikan ide penting dengan kalimat mereka sendiri, menafsirkan ide kemudian menyatakan masalah matematika ke dalam model matematika. Hal tersebut seperti dijelaskan oleh Supriadi, dkk. (2015), proses berpikir yang terjadi dalam benak siswa akan berakhir sampai diketemukan jawaban. Proses atau jalannya berpikir itu ada tiga langkah, yaitu: (1) pembentukan pengertian, (2) pembentukan pendapat, dan (3) penarikan kesimpulan. Pada tahap talk siswa mendiskusikan catatan yang telah mereka buat dan menyatukan jawaban mereka sebagai ke dalam satu kelompok. Pada tahap ini akan terjadi asimilasi karena jawaban yang beragam dalam satu kelompok. Pada tahap write siswa secara individu merumuskan pengetahuan berupa jawaban atas soal dalam bentuk tulisan dengan bahasanya sendiri dan dengan bimbingan dari guru mengungkapkan jawaban yang benar.

Model pembelajaran kooperatif tipe think talk write merupakan salah satu model pembelajaran yang yang dapat meningkatkan kemampuan menulis siswa, meningkatkan penalaran, meningkatkan kemampuan memecahkan masalah, kemampuan pemahaman konsep, meningkatkan kemampuan representasi matematika [Wiyak (2017); Widyanto, dkk (2018); Fajar \& Sudia (2016); Hidayati, dkk (2019); Supandi, dkk (2018)], tahapan dalam penerapan metode pembelajaran think talk write yaitu think (berpikir/dialog reflektif), talk (berbicara/berdiskusi), dan write (menulis) terbukti dapat mendukung siswa dalam mengembangkan kemampuan komunikasi matematika yang mencakup banyak kemampuan kognitif, diantaranya mendengarkan dan membaca (pemahaman) serta berbicara dan menulis (ekspresi). Khususnya pada matematika, ekspresi juga dapat mencakup representasi ideide matematika dengan cara nonlinguistik (Sammons, 2018: 1-2). Hal ini dikarenakan pada tahapan pembelajaran think talk write, siswa diberikan kesempatan untuk mengembangkan kemampuan komunikasi matematika secara individual, dilanjutkan dengan diskusi dimana dalam kegiatan diskusi siswa dapat memperkaya informasi tentang masalah yang diberikan, kemudian menuliskan pemecahan masalah/informasi yang telah diterimanya menggunakan kalimat mereka masing-masing. Pemberian kesempatan kepada siswa untuk mengembangkan kemampuan individualnya, memberi dampak pada meningkatnya kemampuan komunikasi matematika.

\section{SIMPULAN}

Berdasarkan kajian hasil penelitian maka model pembelajaran tipe think talk write dapat digunakan sebagai salah satu sarana untuk meningkatkan kemampuan komunikasi matematika siswa kelas V SD Negeri Kedundang. Alur strategi think talk write dimulai dari keterlibatan siswa dalam berpikir atau berdialog reflektif dengan dirinya sendiri, selanjutnya berbicara dan berbagi ide dengan temannya, sebelum siswa menulis secara umum melatih siswa untuk mencapai semua indikator kemampuan komunikasi matematika. Adanya peningkatan kemampuan komunikasi matematika siswa dari kategori sangat rendah dan rendah meningkat menjadi kategori sedang, tinggi dan sangat tinggi, maka dapat disimpulakan bahwa penrapan model pembelajaran kooperatif tipe think talk write dapat meningkatkan kemampuan komunikasi matematika siswa. Mengingat pentingnya kemampuan komunikasi matematika, hendaknya pembelajaran matematika di sekolah mulai diarahkan untuk memfasilitasi pengembangan kemampuan tersebut bagi siswa. 


\section{DAFTAR PUSTAKA}

Elliot, P. C \& Kenney, M. J. (1996). (Eds) Yearbook of Communication in Mathematics K-12 and Beyond (pp. 168-169). Reston, VA: NCTM)

Fajar, L. O. M. S. \& Sudia, M. (2016). Penerapan Model Pembelajaran TTW (Think-Talk-Write) Untuk Meningkatkan Kemampuan Pemecahan Masalah Matematika Siswa Kelas VIII-5 SMP N 2 Raha. Jurnal Penelitian Pendidikan. Volume 4 No 1 (2016).

Fathoni, M. I., Sumardi, S., \& Supriyadi, S. (2019). "DEFENDS" as An Effective Writing Strategy to Create Students Creativity. International Journal of Language Teaching and Education,3(1), 67-77.

Hidayati, R. Fauzan, A. \& Hakim, R. (2019). Implementation of Think Talk Write (TTW) Strategy to Improve Understanding of Concept and Communication of Mathematics. Proceedings of the $1^{\text {st }}$ International Conference on Innovation in Education (ICoIE 2018): Advances in Social Science, Education and Humanities research.

Iksan, et.al. (2012). Communication Skills Among University Students. Procedia - Social and Behavioral Sciences 59 ( 2012 ) 71 - 76. Doi: 10.1016/j.sbspro.2012.09.247

Limbach, B. \& Waugh, W. (2010). Developing Higher Level Thinking. Journal of Instructional Pedagogies, Vol.3.

Mishra, J. (2015). Effective Ways to Teach Oral Communications Skills to Engineering Students of Chhattishgarh. Journal of Research in Humanities and Social Science. Volume 3-Issue 3 (2015) pp: 47-51)

Mahajan, R. (2015). The Key Role Of Communication Skills In The Life Of Professionals. IOSR Journal Of Humanities And Social Science (IOSR-JHSS) Volume 20, Issue 12, Ver. II (Dec. 2015) PP 3639 e-ISSN: 2279-0837, p-ISSN: 2279-0845.

Maulidya, A. (2018). Berpikir dan Problem Solving. Jurnal Ihya Al-Arabiyah: Jurnal Pendidikan Bahasa dan Sastra Arab. Vol 4 No.1

Pantaleon, K.V., Juniati, D., \& Lukito, A. (2018). The oral Mathematical Communication Profile of Prospective Mathematics Teacher in Mathematics Proving. Journal of Physics: Conf Series 1108 (2018)012008.

Prayitno, S., Suwarsono, St., \& Siswono, T. Y. E. (2013). Identify Indicators Mathematical communication skills Students in solving mathematics questions Institute on every Grade. KNPM V, the Association of Indonesian mathematics, June 2013:384-389.

Puspa, S., Riyadi, R., \& Subanti, S. (2019). Profile Of Mathematical Communication Skills Junior High School Students in Problem Solving. Journal of Physics: Conference Series, Volume 1157, Issue 3. International Conference on Mathematics and Science Education (ICMScE 2018). IOP Publishing.

Sammons, L. (2018). Teaching Students to Communicate Mathematically. Virginia USA: ASCD.

Schneider, P. (2011). Writing Alone and With Others. New York: Oxford University Press

Siahaan, M. M. L. \& Napitupulu, E. E. (2018). The Difference of Students' Mathematical Communication Ability Taught by Cooperative Learning Model Think Talk Write Type and Numbered Head Together Type. Scholaria: Jurnal Pendidikan dan Kebudayaan Vol. 8, No. 3 Tahun 2018. Salatiga: UKSW.

Sofiyah, K., Surya, E., \& Syahputra, E. (2017). Membangun Kemampuan Pemecahan Masalah Dan Kemandirian Belajar Siswa Melalui Pembelajaran Geometri Berbasis Pendidikan Matematika Realistik. Dapat didownload di https://www.researchgate.net/ publication/321905622. Diakses 2 September 2018.

Supandi, dkk. (2018). Think-Talk-Write Model for Improving Students' Ability in Mathematical Representation. International Journal of Instruction. Vol.11,No.3. pp 77-90. 
Peningkatan Kemampuan Komunikasi Matematika Siswa SD Kelas V Melalui Tipe Pembelajaran Think Talk Write (TTW) (Novy Trisnani)

Supriadi, D., dkk. (2015). Analisis Proses Berpikir Siswa dalam Memecahkan Masalah Matematika Berdasarkan Lahkah Polya Ditinjau Dari Kecerdasan Emosionl Siswa Kelas VIII. Jurnal Pendidikan Pembelajaran Matematika. Vol 3, No.2, hal 204-214.

Trisnani, N. (2012). Komparasi Keefektifan Model Pembelajaran Kooperatif Tipe Team Assisted Individualization Dan Think Talk Write Ditinjau Dari Minat Dan Kemampuan Komunikasi Matematika Siswa SD. Thesis. Yogyakarta: UNY.

Widyanto, P., Wahyudi, \& Indarini, E. (2018). Think Talk Write Method Implementation to Improve Fourth-grade srudents' reasoning Skill. Journal LIK: Kembaran Ilmu Kependidikan Vol. 47 No. 1 (2018).

Wiyak \& Ansori, A. S. (2013). Think-Talk-Write (TTW) As A Strategy to Improve Students' Ability in Teaching Writing Descriptive Text. Journal Eternal. Volume 4 No 1 (2013).

Yamin, M. \& Ansari, B. I. (2009). Taktik mengembangkan Kemampuan Individual Siswa. Jakarta: Gaung Persada Pers Jakarta. 